\title{
Knowledge Sharing: Will it Enhance the Link between Self-Efficacy and Workplace Spirituality?
}

\author{
Rohini S. Nair, V. Sivakumar
}

\begin{abstract}
Teachers have a very significant place in a society. They shoulder the responsibility of building the capacities of the future generations. For this, teachers must have a sense of belief in their capabilities. The sense of self-efficacy makes them connected to their work and workplace and also instils a sense of performing work that is meaningful. This helps in strengthening workplace spirituality. In the educational field, knowledge is of utmost importance. Sharing knowledge improves the development of, both, the individual and the organization. The intention and willingness to share knowledge depends on several factors. This study tries to understand the association of selfefficacy and workplace spirituality. The study also attempts to understand the moderating role of knowledge sharing intention on the relationship between self-efficacy and workplace spirituality. The result of the study shows that there is a significant positive relationship between self-efficacy and workplace spirituality. Knowledge sharing intention was also found to have a significant moderating effect on this relationship.

Keywords: - Teachers, Self-efficacy, Workplace Spirituality, Knowledge Sharing Intention, Moderating effect.
\end{abstract}

\section{INTRODUCTION}

Transformation in the workplace is absolutely necessary for organizations to achieve sustainable development. For this, organizations require employees who are capable of contributing greatly to the performance of the organization. Only employees who have high assurance in their capability are likely to engage in challenging and valuable tasks. People who doubt their capabilities are unlikely to involve in such tasks because they see them as a threat. Organizations, thus require employees who believe in their ability to perform the duties and responsibilities vested with the responsibility of grooming the future generations to be efficient and to inculcate a strong personality in them. "Teaching is a profession that demands calling and commitment beyond human's limitations" (Kumar, S., 2018). The behavior, the style of interaction of a teacher with students and their overall classroom practices greatly impact the students. Lack of capability and commitment from the part of teachers will adversely affect the mindset of the students resulting in behavioral and developmental issues. Kerala is among the states in India with highest literacy rate. The state has several motivators of education. The government support to promoting education and educational institutions is one of the factors. Ernakulam, one of the districts of Kerala, is known as the commercial capital.

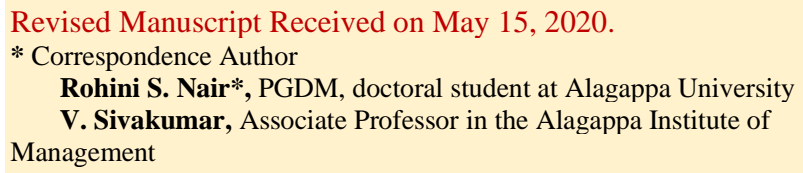

(C) The Authors. Published by Blue Eyes Intelligence Engineering and Sciences Publication (BEIESP). This is an open access article under the CC BY-NC-ND license (http://creativecommons.org/licenses/by-nc-nd/4.0/) efficiently. This particularly applies to teachers, who are

According to the 2011 Census, Ernakulam has occupies a place among the top ten highest literate districts of India. Ernakulam also has numerous schools and colleges. This study focuses on the teaching community in Ernakulam district. An effective teacher inculcates an interest in learning among the students and provide timely support for their overall development. The ability of a teacher to positively influence students depends on the belief in their capabilities. Researchers have proved that self-efficacy is an indispensable quality of a good teacher. Self-efficacy is a person's belief about being able to successfully complete any task (Bandura, 1977). This is one of the most important factors that affect an employee's perception towards his/her ability, which in turn, influence the level of motivation, and performance (Bandura, 1997). Several researchers have also proven that self-efficacy has a significant relationship with job satisfaction and many other work related outcomes. The extent of involvement and connectedness to the work and workplace is said to be dependent on the feeling of being efficient. Self-efficacy also decides the way in which an individual perceive any task and fulfill responsibilities in the workplace. Self-efficacy is also found to reduce the level of anxiety and stress in the workplace. This indicates that individuals seem to be more relaxed and free and enjoy their work. This feeling of involvement and connection can lead to the inculcation of the feeling of workplace spirituality. Workplace spirituality, according to Dehler and Welsh (2003) is, taking an individual in a whole sense and considering the various needs, including, emotional, empathetic as well as spiritual requirements. People seek to achieve elements that are over and above the material and monetary reward from their workplace. One of them, is the search for work that is significant in every respect and the enjoyment that they derive from it. This enjoyment is converted into positive energy and enthusiasm that will result in achieving the goals of organization. It will also result in a match between the values and goals of individual and organization. Workplace spirituality is the ultimate discover and experience of work that is important and meaningful and which also result in happiness and overall satisfaction. An intensification of interest of researchers towards workplace spirituality has been observed since recent past. One of the reasons pointed out for this by Neck and Milliman (1994), Ray (1992), Maynard (1992) is that, with advancement in almost every field including, technology and other ideas, people tend to search for greater meaningful work and better connection in both their personal and professional lives, as they spend majority of their time at their workplace.

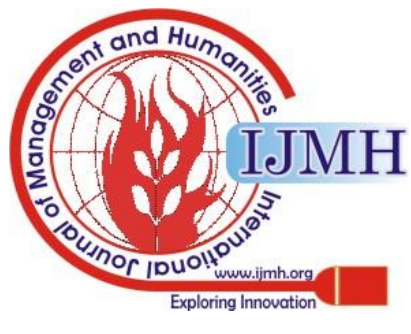


Several benefits are also associated with WPS. WPS is found to augment creativity as well as the elements of trust and honesty (Freshman 1999; Wagner-Marsh and Conely, 1999). It is also found to greatly affect commitment and ability to solve problems effectively and decrease burnout (Delbecq, 1999; Leigh, 1997; Tischler et.al., 2002). Workplace spirituality improves satisfaction, ultimately affecting the progress of organization in a positive manner (Duchon and Plowman 2005). This construct, in short, affects each and every component of an organization (Groen, 2001). As rightly said by Teh \& Yong (2011), knowledge is a critical element for achieving competitiveness. Sharing of knowledge among employees is necessary for the growth of organizations. Knowledge sharing (KS), according to Wang \& Noe, (2010), is essential for every organization and is concerned with the inclination of employees to share and impart the knowledge acquired by them to their co-workers in order to steadily increase organization's performance. Though beneficial to themselves and organization, this phenomenon is rarely seen in organizations due to the natural tendency of people to hide knowledge and not share with others (Davenport \& Prusak, 1998). This, indeed, is a challenge for the organizations. Employees require to be interconnected with their work, workplace and their co-workers in order to freely share and gain knowledge. It is found that one of the strongest predictors of knowledge sharing behavior is the internal satisfaction derived out of helping others through imparting knowledge rather than the material and monetary rewards they gain (Lin, 2007).

\section{STATEMENT OF THE PROBLEM}

Educational structure is of utmost importance to every nation as it adds strength to the building of a strong nation. In an educational structure, teachers occupy the vital place. Teachers play a crucial role in facilitating the progress of the society. The growth depends on the extent to which teachers are contented with the jobs and devoted to contribute to the advancement of their organizations. They help to mould children into morally responsible and dedicated individuals. It is highly essential for them to be well connected to their work and work setting. This feeling of connectedness and finding work to be meaningful gives rise to the construct of workplace spirituality. The feeling of being efficient to perform their duties effectively determines how well they are able to shape the citizens of tomorrow. In an educational setup, knowledge is the one and only thing that is of utmost importance. The intention to disseminate knowledge among themselves is highly essential to improve and maintain standards. Another view to the phenomenon of KSI is that, being efficient and the feeling of attachment to the workplace and co-workers might not necessarily motivate employees to share knowledge. This study, thus, attempts to recognize the relationship between self-efficacy and workplace spirituality among the teachers and the moderating role of knowledge sharing intention in this relationship.

\section{THEORETICAL FRAMEWORK}

\section{Workplace Spirituality}

Workplace Spirituality began in the early 1920s. It is expressed to be associated with the inner consciousness of individuals and also a feeling of experience which result in self-enlightenment and a busrt of positive energy (Guillory, 2000; Dehler and Welsh, 1994; Barnett, Krell, and Sendry, 1999). According to the idea of Gibbons (2000), the experience of workplace spirituality is about feeling complete at work by experiencing a deep sense of connection with the workplace and its values. This is a complex framework that involves several aspects, including, understanding an individual's purpose or meaning in life, building a strong rapport with work, workplace and colleagues, all of which is the result of the match between the values and ideals of oneself and that of the organization (Mitroff and Denton, 1999). It is also understood as an experience to realize the fact that employees are not just a pair of hands, but they also have a mind that search for fulfilment through an interaction of their work, workplace and co-workers (Ashmos and Duchon, 2000). Workplace spirituality originated from the theory of organization behavior. It emphasizes the significance of human behavior in the organization that leads to the desired outcomes. The theory tries to understand why people behave in certain ways. The theory also understands the significance of values of an individual in the context of an organization and the way in which this is converted to actions which result in the benefit of both the individual and the organization. Researchers, in short, began to focus on the human experience in working environments and how it ultimately impacts on the way organization functions, handles change and develops. Being truly related to the various aspects of human behavior, workplace spirituality is a construct which combines the concern for oneself as well as for others. This is, in fact, an element of organizational culture that has the potential to directly impact the behaviors and actions of employees.

The concept of workplace spirituality is also found to include an element consisting of an interaction with a higher power. Several researchers consider it to be the strong adherence of an individual towards his/her values that leads and controls the individual's actions, rather than the influence of a supreme power. According to the research of Giacalone and Jurkiewicz (2003), workplace spirituality is a holistic framework which is the reflection of organizational culture, and it is through this environment that employees experience a strong connection to the work context which result in a sense of completeness and positivity. "

One of the dimensions of workplace spirituality, transcendence, lead to misunderstanding spirituality as same as the aspect of religion. Researchers have made clear distinction between the concepts of spirituality and religion. Duchon and Plowman (2005) have tried to distinguish between religion and spirituality. They explain religion to be a set of belief system which is organized and followed by people, whereas, spirituality is a mode of life and is related with uncovering and understanding the true essence of life and to build meaningful connections with work and workplace.

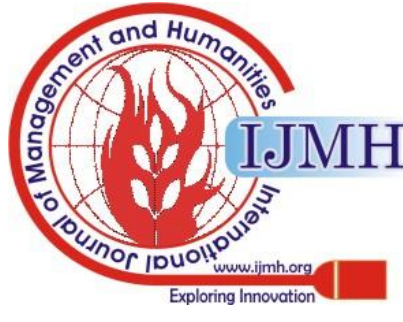


Religion is a system of beliefs and rituals which are established in the society and are followed by people and spirituality is, in fact a feeling and an experience of leading a fulfilling life by performing meaningful work which result in satisfaction and happiness (Marques et al., 2017). Workplace spirituality does not in any sense related to any religion or tradition. They are poles apart and workplace spirituality focuses on personal value system (Afsar, B., \& Rehman, M, 2015).

The concept of workplace spirituality was placed on a scale or a continuum, which range from high workplace spirituality to low workplace spirituality. It is also said to consist of three self-identity levels, including, individual, group and organizational levels. It describes the level at which the representation of self is done. (Ashforth and Johnson, 2001). The continuum helps explain the extent of experience of workplace spirituality by an individual. The spirituality continuum from low to high consists of, different types of self-identity including, individual self-identity, relational self-identity, collective self-identity, and transcendental self-identity. Greater emphasis on self and a greater separateness between oneself and others is an indication of an experience of lower spirituality level. Higher experience of spirituality indicates greater connection between oneself and others and more interdependence between these parties (Liu and Robertson, 2011). Individuals with greater workplace spirituality exhibit greater amounts of connection and several other positive characteristics.

Workplace spirituality is associated with several positive outcomes for, both, the employees and the organization on a greater extent. It is found to result in job satisfaction, retention, reduced stress level, organizational citizenship behavior and many more (Kolodinsky et al., 2008). It is a feeling that is inculcated in the mind of an individual from the love towards and association with one's profession and also from the values in the work. Workplace spirituality instils a sense of meaning in one's life and also improves self-awareness, useful existence and knowledge that affects one's life-long actions and results (Kumar, S., 2018). It indicates a constant strive to find enrichment in personal and professional life through building and maintaining virtuous relationships and an alignment with the values of the organization. The concept is highly complex framework which is multi-faceted. Many researchers consider the term 'a meaningful workplace' as analogous to 'spirituality in the promoting and sustaining a workplace that is meaningful and beneficial for even the society at large (Steenkamp and Basson, 2013).

Workplace spirituality promotes the sense of connection with others that increases the element of trust between people, which naturally instils a feeling of co-operation between employees in an organization and transforms the culture of organization into a highly positive and optimistic one which directly influences the motivation and improves the performance of individuals, groups and organization (Afsar, B., \& Rehman, M., 2015). An individual who experience workplace spirituality view oneself as spiritual beings who search for meaning to nourish their life through rapport building in the workplace scenario (Milliman et al., workplace' and they consider this as a significant element in

2003). According to Afsar, B., \& Rehman, M., (2015), workplace spirituality is based on the values of empathy, connection, patience, tolerance which are integrated with the organizational environment which shape the individual values of employees.

Workplace spirituality helps people to completely express themselves by indulging in their meaningful work. Workplace spirituality is understood by many as a construct that elevates the level of meaningfulness at various levels, including, individual and organizational (Kolodinsky et al. 2008; Pawar 2008). According to them, there are different interpretations of workplace spirituality at various levels. At the individual level, it is a highly positive experience. At the group levels, it is a sense of connection and at the organizational level, it is a reflection of organization's culture which consists of spiritual values and also shapes the behavior of employees and affects decision making.

Workplace spirituality has been found to offer several benefits to the organization. It has favourable effects on the satisfaction and overall well-being of individuals (Milliman et al., 1994). Moore, T. W. (2008) found that workplace spirituality greatly impacts the relationship between organizations and also promote creativity, commitment and overall efficiency. Pathak, D. (2012) found that workplace spirituality provides people with the required internal and external resources to help people to explore and understand the innate creative talent of an individual and to provide people with sufficient opportunities to exercise creativity in the organizational set up. The works of Ajala, E.M. (2013) found that as people are highly motivated and committed, they are able to find better meaning as well as contentment in engaging with their work and workplace. It will automatically decrease the amount of burnout and stress experienced by employee and promote physical and psychological wellbeing resulting in greater performance.

Milliman, et. al. (2003) identifies two certain aspects in workplace spirituality - sense of community and meaningful work. These aspects considers the entire society as well and the means of adding value to it by performing work which is meaningful. This feeling arises due to the inculcation of values like empathy, altruism, trust and so on. Harrington et al. (2001) proposed that when employees experience greater connection in the workplace and alignment between employee's and organization's values, it will help them uncover the true meaning at work.

\section{Dimensions of Workplace Spirituality}

Ashmos and Duchon, (2000) have suggested that workplace spirituality can be seen at three levels in the organization. The following figure illustrates this. 


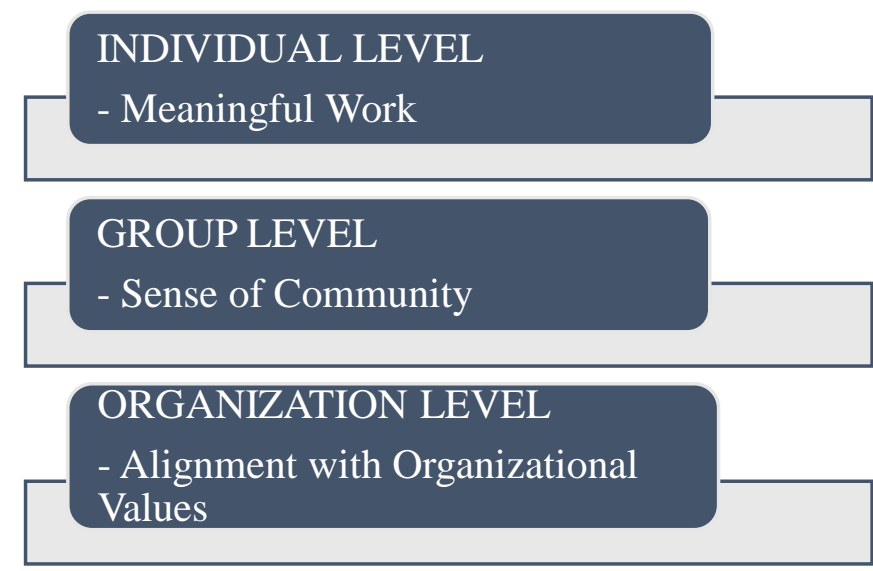

Figure 1Levels of Workplace Spirituality

\section{Workplace Spirituality at the Individual Level Meaningful work}

This dimension involves having a profound feeling of meaning and drive in one's effort. An individual understand the real meaning of work when one is provided an opportunity to work for a larger cause (Srinivas, 2008). This work truly reflects the way of discovering oneself, internally and externally, and also as a means of serving the entire community (Mirvis, 1997). When employees have the opportunity to work for a greater cause of society, it increases the desire to connect to others and to be a driving force for change for the whole humanity, at large (Ashmos \& Duchon, 2000). The extent of workplace spirituality experience at work truly depends on the inner self of an individual. It also decides the interest to involve in the various activities of organization to add more value to every lives, including one's own (Hawley, 1993). It is about searching for much deeper purpose of life and fulfilling it through performing work and supporting others through the work that they perceive to be meaningful.

\section{Workplace Spirituality at the Group Level Sense of Community}

This dimension is about having a profound and significant connection to, or relationship with, others, (Ashmos and Duchon, 2000). It is about an individual and co-workers sharing a common sense of purpose and also helping and supporting each other. As per concept of 'need of every individual to belong in community' stated by Baumeister and Leary (1995), everyone have an inner tendency to belong and be a part of the society/community which ultimately results in a great sense of positivity leading to happiness and satisfaction. According to Maynard (1992) and Miller (1992), the feeling of belongingness at workplace inculcates from the desire to develop meaningful connections with each other and one's inner self. This dimension involves strong feeling of connection among people, co-operation, and liberty to express one's thoughts and feelings and sincere caring.

\section{Workplace Spirituality at the Organization Level}

\section{Alignment with Organizational Values}

Milliman et al. (2003) identified that the dimension at the organizational level is about a strong match between the goals and value system of individual and organization. This is about an individual's feeling of a strong sense of orientation and match between the morals and ideals of a person and organization. Greater the match between their values and ideals, greater the level of dedication and loyalty towards the organization and closely identifies with the organization (Khari, Chitra \& Sinha, Shuchi, 2017). Alignment between individual's and organization's values indicate the greater purpose of one's life and work and the contributions one should make to the society (Ashmos and Duchon, 2000).

\section{Self-Efficacy}

Bandura, A. (1994) has defined self-efficacy as the confidence of an individual about one's own competences and the way it impacts one's performance and also about their ability to control events and situations that affect them. Self-efficacy views decide the emotional, cognitive and behavioral aspects of an individual. Self-efficacy has a huge influence on the self-confidence and self-esteem of an individual (Kanter, 2006; Brockner, 1988). A person with a high sense of self-efficacy believes in oneself greatly to make huge accomplishments. People with high self-efficacy tend to approach and accept challenging tasks and perform to their maximum ability rather than considering it as a threat. These people also do not avoid any difficult situations considering them to be a high risk. They set challenging goals for themselves and uphold robust obligation towards them. They remain strong even in the face of failure. They understand and accept that poor performance is the result of their insufficient effort form their part. They approach every situation with high level of confidence that they can succeed and control them. The quality to be highly efficacious helps people to produce success, thereby reducing stress and anxiety and promoting happiness and satisfaction (Bandura, A., 1994). People with lower self-efficacy, on the contrary, have aspirations which are very low and are not confident to make commitment and accept challenging tasks and complete it successfully. They tend to give up very easily during difficult situations which lead to be victims of stress, anxiety and even depression.

Many researchers have discovered the strong link among the self-efficacy of teachers and student achievement. Teacher's self-efficacy, is in fact, the key factor that determines their ability to guide students to achieve success. It is found that teachers with a high sense of self-efficacy provide greater support to students and are successful in creating an overall positive environment in the classroom. They are also found to be much more open-minded and are always optimistic. Self-efficacy is the most effective element that builds self-belief and persistence in individuals and provides strength to face and overcome any obstacle and also to build a positive mindset in them (Clark and Bates, 2013). Highly effective teachers have good aptitude and they have the ability to clearly define and deploy strategies and actions that lead to success. They also have the ability to solve any issue and challenge. They are also confident enough to be learn and reflect on experiences and make right decisions to make future actions successful and have the ability to help and support students (Clark and Bates, 2013).

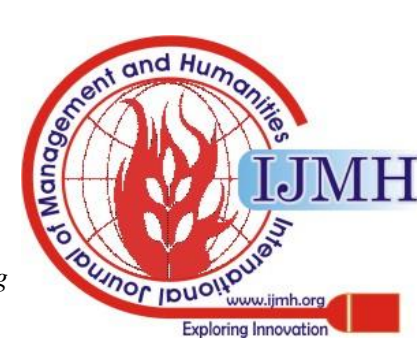


The concept of self-efficacy is based on the social cognitive theory suggested by Bandura (1999). According to Nevid (2009), social cognitive theory proposes that people respond to environmental situations through actively listening and interpreting information from them. In the view of Locke and Latham (2002), the theory explains the reasons for physiological arousal and includes moral judgment and also includes the concept of self-efficacy. The theory also seeks to explain that the individual outcomes are the result of their own motivation, behaviour and judgement. The behavioural scientists emphasize the significance of external stimuli in determining the actions and outcomes of an individual and, to an extent, ignores self-processes that result in certain behaviours. But, Bandura (2005) gives more emphasis on internal rather than external stimuli as this is most significant in understanding and deciding the consequences of an individual's actions. According to him, people make sense of their own actions through introspection and emphasizing on their mind.

Social cognitive theory includes mechanisms for selfregulation as well as learning. It describes the cognitive processes that result in learning and their ability to act according to available information, depends upon their unique personal characteristics. If the employee doesn't have belief in their ability, they are most likely to be under high stress and anxiety and also lack self-confidence to complete tasks successfully and lead to failure (Stajkovic and Sommer, 2000). If a teacher is low on confidence, he/she cannot actively inspire students to attempt better methods. But, on the other hand, a teacher who is confident inspire students, instigate innovation and prepare them to take up challenging tasks. They create a truly learning and enriching environment and experience for the students and convert them into capable and competent individuals with positive mind-set.

Self-efficacy has three key dimensions. This includes, magnitude, strength and generality. The first dimension refers to the extent of difficulty and complexity of a task which an employee has confidence in achieving (Stajkovic and Luthans, 2002). Strength is the confidence of an employee to perform tasks that are difficult. Rather, it is the strength of self-efficacy of an employee to handle complex tasks. Generality is the applicability of similar levels of selfefficacy in similar kinds of activities. The sense of selfefficacy is derived from an individual's reflection of themselves derived from their intentions, plans and strategies to enhance learning and discover their inner strength through the process (Shaari, 2014).

Self-efficacy is found to be linked to several other outcomes. Albert Bandura and Edwin Locke (2003), from their research have concluded that self-efficacy is a dominant predictor of performance. Self-efficacy is also found to have a connection with quality of work life as selfefficacy is a sense of feeling or an internal element (Bandura, 1977). People's belief about oneself directly influence the behavior and related change in behavior. People perceives elements about their capabilities and competencies, based on which their behavior is shaped. Amtmann, et. al. (2012) have found a strong connection between self-efficacy and psychological wellbeing. Research of Prilleltensky and Prilleltensky (2007) showed that, self-efficacy also decide on the extent of interaction one has with others which will determine the well-being and quality of life. Amtmann, et al. (2012) noted that selfefficacy beliefs directly influence the challenges and actions one accepts and selects to complete efficaciously. Selfefficacy beliefs decide the motivation level, the amount of effort one takes and the level of anxiety and stress one experience and also the extent of an individual's perseverance. Researchers have indicated that, people perform their daily activities and deal with tasks with different self-efficacy levels which is the result of many other elements, including, prior experience, personal qualities, and so on.

There are several sources of self-efficacy. Bandura (1997) has recognized four primary foundations of selfefficacy: - past performance, vicarious experience, verbal persuasion, and emotional cues. The most important source of self-efficacy, according to Bandura, is past performance. In his opinion, people who have had a positive experience and were able to complete a task successfully, are more confident in performing similar tasks in future as well compared to people who have failed in it previously. Vicarious experience is the confidence derived by an individual through watching a co-worker flourish in their work. Verbal persuasion is about making people believe that they are capable of efficiently and successfully completing a job. Emotional cues is about the physiological symptoms that a person might experience when he/she presumes failure in performing a task that is highly challenging and difficult to perform. Researchers suggest that the theories of goal-setting and self-efficacy are complementary to each other. The higher the targets set by leaders for an employee, the self-efficacy levels of employees' increases as they tend to be motivated to achieve it to prove themselves as capable.

\section{Knowledge Sharing Behavior}

Knowledge sharing (KS) is considered to be a crucial element of knowledge management and is an essential competitive approach to sustain organizations' competitive advantage (Takeuchi N, 1995). According to Chow \& Chan (2008) knowledge sharing is considered as the mechanism through which individual knowledge into organizational knowledge. Wang and Noe (2010) explained knowledge sharing as the technique to share information and improve the knowledge base of oneself and others on order to promote creative ideas and implement them to raise the overall standard. Lindsey (2006) considers it as, the method of acquiring knowledge and disseminating and using them effectively and efficiently. Knowledge sharing is a process that can occur anyway if situation permits. It can happen between individuals, within groups, between groups, and even between organizations (King, WR 2006). The knowledge sharing attitude of the employees facilitates learning process through more and better opportunities ultimately impacting the overall performance of organization. (Huber, G.P., 1991; Hansen, M.T. et al., 2002) 
Knowledge sharing is described by researchers as, an essential strategy to share both forms of knowledge among organizational members which result in the creation of new knowledge. The realization of the process of sharing knowledge depends highly on the willingness of people to share knowledge with others which is dependent on others factors (Connelly \& Kelloway, 2003). There are several personal, organizational and situational factors affecting knowledge sharing in organizations. These factors affecting knowledge sharing can be divided based on levels, into individual, group and organizational level factors. The major motivating factor for exhibiting knowledge sharing behavior at the individual level is the interest or focus on personal gains. The genuine interest in supporting community plays the role of the motivator in promoting organizational level sharing of knowledge (Bock et al., 2005).

Knowledge sharing is the transfer of knowledge voluntarily by an individual to others in the organization or to a group or team in an organization environment (Dyer, Kale \& Singh 2004). The willingness to share knowledge with others is a key individual factor of the behavior of knowledge sharing. Though KS is very beneficial to the individual as well as the organization, majority of people ponder over the necessity to share knowledge as this is the most prized resource. Some even feel that sharing knowledge might lead to a threatening situation for them in their work because other people may acquire knowledge from the individual and use it for their own benefit to gain credit (Kramer 1999). Individuals, thus have a natural inclination to hide knowledge from others (Probst, Raub and Romhardt, 2000; Tiwana, 2000).

The increasing requirement for quality education has made it mandatory for teachers to continue learning throughout their careers (Vermuelen, et., al., 2014). According to Bakkenes et al. (2010), teachers re the prime sources of knowledge and are involved in day-today learning and knowledge acquisition and are also involved in formulating new effective methods. Honingh and Hooge (2014) emphasized on the learning potential of teachers working together. Through the process of knowledge sharing with colleagues, teachers can collectively generate new knowledge which stimulates the formation of teaching techniques which are highly effective (Woerkom 2004).

Teachers share both tacit and explicit knowledge with each other. As rightly said by Vermuelen, et. al. (2014), through sharing of knowledge, teachers uncover better methods of teaching and interact well with students and can also inspire them as well as the whole teacher community. The discussions can also lead to the development of new pedagogy which wholly raise the quality of the education system and provide better content and insights to students. The intention to share knowledge is affected by several factors including, reciprocity, improving reputation and many more factors (Rahab and Wahyuni, 2013). Some employees share knowledge because they find enjoyment and satisfaction in helping others and some others share knowledge with the intention to get something in return.

Knowledge sharing intention is explained by researchers using the framework of Theory of Reasoned Action (TRA). This theory originated from the field of social psychology. The process of knowledge sharing is a voluntary process.

The theory explains the attitude of an individual towards the behaviour of sharing knowledge which ultimately leads to the intention to share knowledge. It places emphasis on the attitudes, behaviors and mindset of people that affect their intention towards sharing knowledge (Rahab and Wahyuni, 2013). According to them, the tendency to share knowledge is the result of attitudinal and behavioral belief and outcomes that inculcates a positive/negative feeling in an individual towards the most valuable process of disseminating acquired knowledge with co-workers in organization. Positive attitude increases the tendency and willingness of individuals to share knowledge. Contextual factors also play a great role in shaping an individual's knowledge sharing intention. Zhang (2013) pointed out that employees are inspired to share knowledge due to several organizational, personal and societal factors.

It is essential to make employees' aware about the benefits of sharing knowledge and they should be convinced to do so to reap the several benefits which can be derived out of it (McWilliams \& Stepanek, 1998). The most important factor that is found to influence KS behavior is the intrinsic motivation. In the words of Bock et al. (2005), Lin (2007), Chennamaneni, Teng, \& Raja (2012), if an individual believes that if the process of knowledge sharing is a waste of time and resource, he/she might have a negative attitude towards knowledge sharing. Contrary to this, if an individual believes that knowledge sharing leads to several positive outcomes, including personal satisfaction and happiness in helping others, they tend to have a more positive attitude towards it and, thus, engage in the process. The most important predictor of the behavior of knowledge sharing is the internal motivation and satisfaction an individual derives from sharing knowledge, rather than other monetary external rewards. The organizations must ensure that the employees are driven to share and give their knowledge happily and with pleasure so that they directly contribute to the attainment of organizational success. Some conditions have been pointed out by Skyme (2000) which motivate people to happily share their knowledge. This includes, the recognition of value addition through the process, a genuine feeling of care and mindset to support others, the feeling to receive respect from others and so on.

There are certain factors that influence KS behavior. The following figure illustrates this.

Published By:

Blue Eyes Intelligence Engineering \& Sciences Publication 


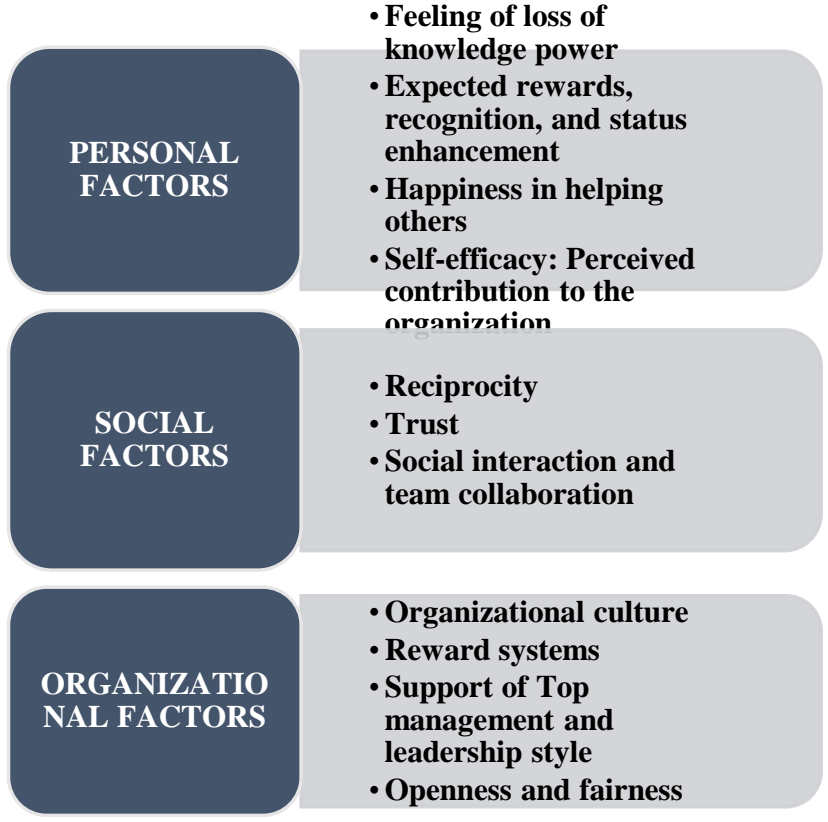

Figure 2 Factors Influencing KS Behavior

Knowledge sharing is considered to be a process by which individuals uncover new thoughts and ideas collectively for the benefit of oneself, others and overall organization. According to Reinholt, M., Pedersen, T. and Foss, N.J. (2011), employees are the source of this process and they must indulge in acquiring and providing knowledge to others. The system of knowledge sharing is a process which is highly interactive and it is an exhibition of an exchange behavior between people (Cerne, Nerstad, Dysvik, et al., 2014). Sharing knowledge is considered a way of helping others and this can intensify the self-worth and self-respect of the individual (Orr, 1990). This results in intrinsic enjoyment for the individual.

\section{Self-Efficacy, Workplace Spirituality and Knowledge Sharing Intention}

Self-efficacy, a person's belief in one's own capability to perform the duties and responsibilities, is associated with several constructive outcomes for the individual as well as the organization. The teaching profession demands teachers to be self-efficacious as this will decide the impact that the teacher creates on the students. Usop, et.al. (2013) has rightly pointed out that, a teacher's efficiency to teach and handle classes has a prominent role in inculcating an interest in the minds of students towards learning and achieving excellence academically as well. The feeling of being able to perform the job well will, undoubtedly lead to the development of connection to the work and the overall work setting. When people consider their work to be the most inspiring element in their life, they consider it to be truly meaningful thereby enhancing their motivation, commitment and overall performance (Paloutzian et al. 2003; Reave, 2005). Research suggests that, self-efficacy leads to increasing an individual's adaptability, performance, co-operation, trust and commitment. This is, thus, suggestive of the development of the construct of workplace spirituality. The experience of workplace spirituality offers a sense of direction, purpose and a feeling of togetherness and connection which is achieved through greater levels of employees a sense of community and connectedness through higher belongingness and commitment (Duchon \& Plowman, 2005; Fairholm, 1996; Milliman, Ferguson, Trickett and Condemi, 1999). Workplace spirituality, according to Giacalone and Jurkiewicz (2003), prevails in the culture and increases peer knowledge and it enables their feelings toward others.

Hypothesis 1:- Self-efficacy will have a significant positive impact on workplace spirituality.

Employees in any organization are required to create a culture of knowledge sharing, which has a strong positive impact on the individuals and the organization. Several reasons have been pointed out for the willingness to share knowledge. Among several factors contributing to the interest in sharing knowledge, belief in oneself, efficacy, extra role behavior and also climate of organization are some of the important ones (Lin, 2007; Teh \& Yong, 2011). The theory of mutual exchange has been found to act as a major factor that influence the intention to share knowledge. Wasko and Faraj (2000) have found that, employees experience a strong connection with co-workers, great satisfaction and happiness through sharing their knowledge with others. Constant et al. (1994) have attempted a study which explains that people who are more interested in sharing knowledge believe that they are working for the betterment of the society. The feeling to share knowledge is completely dependent on the individual. Some individuals might want to share knowledge, whereas some others, in spite of being capable, will not want to. So, it is important to understand if there exists an intention to share knowledge among teachers, and if so, how does it affect the relationship between self-efficacy and workplace spirituality.

Hypothesis 2:- Knowledge sharing intention has a positive moderating effect on the relationship between self-efficacy and workplace spirituality.

\section{PROPOSED MODEL}

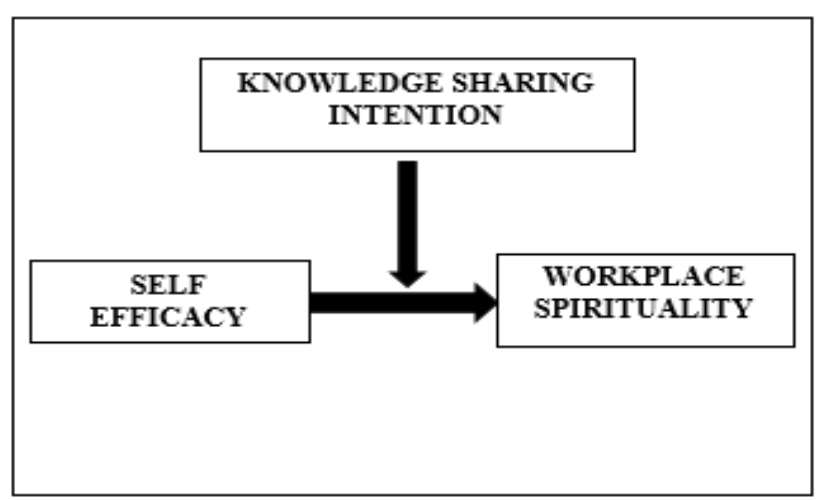

Figure 3 Proposed Model for the Study

\section{METHODOLOGY OF STUDY}

The research design of the study is descriptive. The study was conducted among the teachers of the government schools in Ernakulam district.

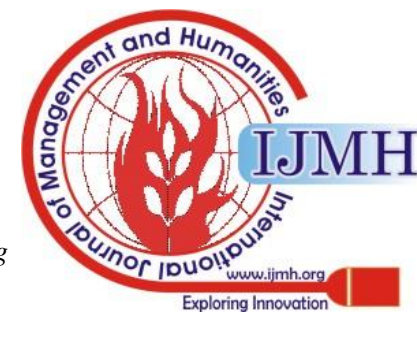


The study is limited to Ernakulam as the researcher had personally visited every respondent and explained the constructs, especially the construct of workplace spirituality, as the chances of misunderstanding were high. 448 questionnaires were distributed to the respondents. Out of this, 392 questionnaires were returned by the respondents and after the process of data cleaning, 366 questionnaires were found to be usable for the study. The questionnaire used five point likert scale wherein $1=$ "strongly disagree", 2 = "disagree", 3 = "neutral", 4 = "agree", 5 = "strongly agree". Higher the item scores, higher the level of construct in the study.Self-efficacy was measured using the scale by Schwarzer, R., and Jerusalem, M. (1995). The scale consisted of 10 items including statements like "I can always manage to solve difficult problems if I try hard enough", "It is easy for me to stick to my aims and accomplish my goals" and "I am confident that I can deal efficiently with unexpected events".Workplace spirituality was measured using the scale adopted from Milliman et al. (2003). It consisted of 15 items. The scale contains statements including "I experience a match between the requirements of my work and my values, beliefs and behaviour", "I share a strong sense of purpose and meaning with my co-workers about our work" and "I feel positive about the values prevailing in my organization".

Knowledge sharing intention was measured using the scale developed by Bock et al. (2005). It consisted of 7 items and contains statements like, "me and my colleagues exchange ideas and views through formal and informal conversation", "I am always ready to share and contribute new ideas to achieve the objective of the institution" and "My knowledge sharing improves work processes in the organization".

\section{DATA ANALYSIS AND DISCUSSION OF RESULTS}

The data was analyzed using WarpPLS. The result of the analysis is shown below.

The reliability and validity of measurements instrument were assessed. The Cronbach's alpha, composite reliability (CR), and average variance extracted (AVE) are shown in the below table.

Table 1 Alpha Coefficients, Composite Reliability and

AVE

\begin{tabular}{llll}
\hline Variable & $\begin{array}{l}\text { Alpha } \\
\text { Coefficients }\end{array}$ & $\begin{array}{l}\text { Composite } \\
\text { Reliability }\end{array}$ & AVE \\
\hline Self-efficacy & 0.675 & 0.853 & 0.572 \\
\hline Workplace & 0.804 & 0.884 & 0.768 \\
Spirituality & & & \\
\hline Knowledge & 0.772 & 0.879 & 0.610 \\
Sharing & & & \\
Intention & & &
\end{tabular}

\section{Source: - Data Analysis}

Cronbach's alpha indicate reliability of the scale measurement items used for the study and the results presented in the above table suggest that all measures in this study, ranged from 0.675 to 0.804 , are reliable as recommended by Hair et al. (2003), and well above the required threshold of 0.6 (Goffee, 1996). The validation of the model was assessed using average variance extracted (AVE) values from the measures. As suggested by Chin et al. (2003), acceptable values for composite reliability should be above 0.70 . In this study, the composite reliability values for all variables of the model are exceeding the recommended value of 0.70 . Also, the AVE measured values are also seen to be greater than the generally accepted cut-off value of 0.50 (Fornell and Larcker, 1981).

The loadings of the variables are given below.

Table 2 Cross Loadings

\begin{tabular}{|l|c|c|c|}
\hline & $\begin{array}{c}\text { Self- } \\
\text { Efficacy }\end{array}$ & $\begin{array}{c}\text { Workplace } \\
\text { Spirituality }\end{array}$ & $\begin{array}{c}\text { Knowledge } \\
\text { Sharing } \\
\text { Intention }\end{array}$ \\
\hline Self-Efficacy1 & $(0.741)$ & & \\
\hline Self-Efficacy2 & $(0.643)$ & & \\
\hline Self-Efficacy3 & $(0.721)$ & & \\
\hline Self-Efficacy4 & $(0.709)$ & & \\
\hline Self-Efficacy5 & $(0.717)$ & & \\
\hline Self-Efficacy6 & $(0.663)$ & & \\
\hline Self-Efficacy7 & $(0.684)$ & & \\
\hline Self-Efficacy8 & $(0.695)$ & & \\
\hline Self-Efficacy9 & $(0.674)$ & & \\
\hline Self-Efficacy10 & $(0.657)$ & & \\
\hline Workplace & & $(0.726)$ & \\
Spirituality1 & & & \\
\hline $\begin{array}{l}\text { Workplace } \\
\text { Spirituality2 }\end{array}$ & & $(0.677)$ & \\
\hline Workplace & & & \\
Spirituality3 & & & \\
\hline Workplace & & & \\
Spirituality4 & & & \\
\hline Workplace & & & \\
\hline Worirituality5 & & & \\
\hline Workplace & & & \\
\hline
\end{tabular}




\begin{tabular}{|l|l|l|l|}
\hline $\begin{array}{l}\text { Workplace } \\
\text { Spirituality8 }\end{array}$ & $(0.616)$ & \\
\hline Workplace & & $(0.736)$ & \\
Spirituality9 & & & \\
\hline $\begin{array}{l}\text { Workplace } \\
\text { Spirituality10 }\end{array}$ & & $(0.624)$ & \\
\hline $\begin{array}{l}\text { Workplace } \\
\text { Spirituality11 }\end{array}$ & & $(0.672)$ & \\
\hline $\begin{array}{l}\text { Workplace } \\
\text { Spirituality12 }\end{array}$ & & $(0.684)$ & \\
\hline $\begin{array}{l}\text { Workplace } \\
\text { Spirituality13 }\end{array}$ & & $(0.673)$ & \\
\hline $\begin{array}{l}\text { Workplace } \\
\text { Spirituality14 }\end{array}$ & & $(0.690)$ & \\
\hline $\begin{array}{l}\text { Workplace } \\
\text { Spirituality15 }\end{array}$ & & & \\
\hline $\begin{array}{l}\text { Knowledge } \\
\text { Sharing } \\
\text { Intention1 }\end{array}$ & & $(0.703)$ & \\
\hline $\begin{array}{l}\text { Knowledge } \\
\text { Sharing } \\
\text { Intention2 }\end{array}$ & & & $(0.812)$ \\
\hline $\begin{array}{l}\text { Knowledge } \\
\text { Sharing } \\
\text { Intention3 }\end{array}$ & & & \\
\hline $\begin{array}{l}\text { Knowledge } \\
\text { Sharing } \\
\text { Intention4tion7 }\end{array}$ & & & \\
\hline $\begin{array}{l}\text { Knowledge } \\
\text { Sharing } \\
\text { Intention5 }\end{array}$ & & & \\
\hline Knowledge & & \\
\hline Intention6 & & & \\
\hline Tnowledge & & & \\
\hline
\end{tabular}

The direct effect of self-efficacy on workplace spirituality was assessed.

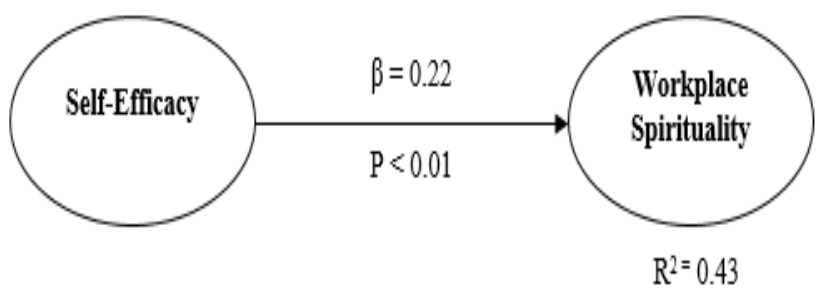

Figure 4

The result of the analysis proved that self-efficacy has a significant effect on workplace spirituality. Workplace spirituality is a highly individual construct. Workplace spirituality plays a tremendously significant role in order to handle unexpected fluctuations in situations and the burnout that result from it (Khorshid, 2015). Individuals must understand the power of one's own mind which will fuel the achievement of satisfaction and positivity in life (Ashmos and Duchon, 2000). In the educational setting, it is essential for teachers to be highly connected to their profession and institution as well as to be self-efficacious in order to impart quality education and to enhance student's development of their competencies. The study also tried to understand the effect of self-efficacy on the various dimensions of workplace spirituality, namely, meaningful work, sense of community and alignment with organizational values. The result of the analysis is shown below.

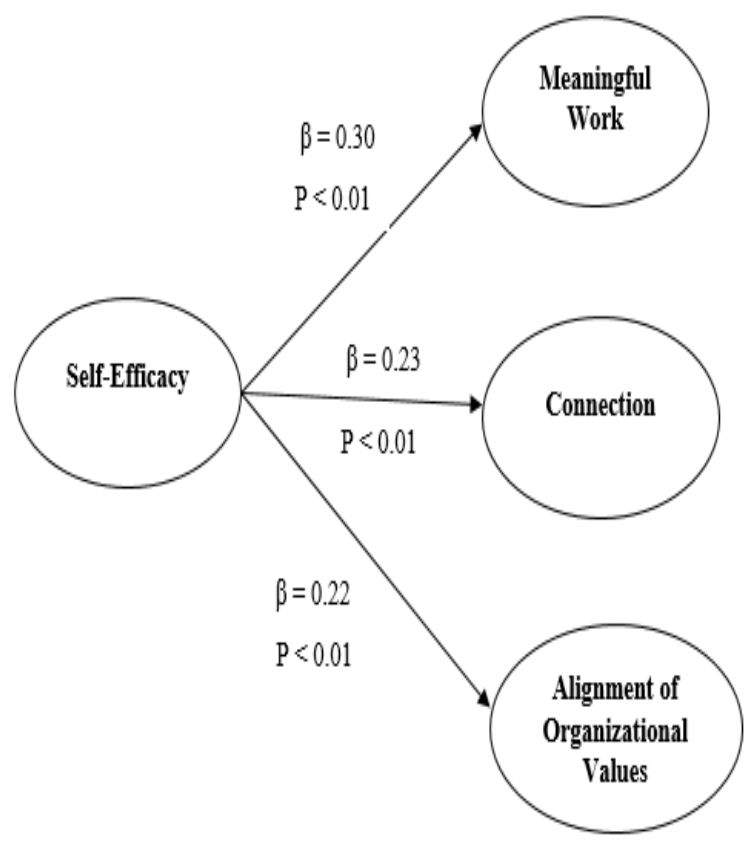

Figure 5

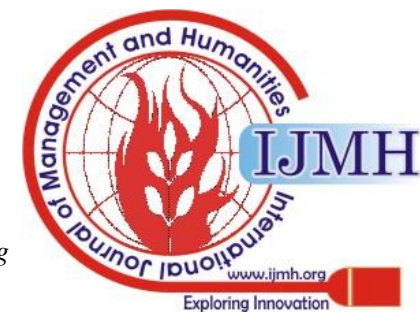


Table 3 Showing the Values

\begin{tabular}{|l|l|l|l|}
\hline Variables & $\begin{array}{l}\text { Meaningful } \\
\text { Work }\end{array}$ & $\begin{array}{l}\text { Sense of } \\
\text { Community }\end{array}$ & $\begin{array}{l}\text { Alignment } \\
\text { with } \\
\text { Organizational } \\
\text { Values }\end{array}$ \\
\hline Self- \\
Efficacy & $\begin{array}{l}\text { Beta Value } \\
=0.30\end{array}$ & $\begin{array}{l}\text { Beta Value } \\
=0.23\end{array}$ & $\begin{array}{l}\text { Beta Value }= \\
0.22\end{array}$ \\
\cline { 2 - 4 } & $\mathrm{P}$ Value & $\begin{array}{l}\mathrm{P} \text { Value }< \\
0.01\end{array}$ & P Value $<0.01$ \\
& $<0.01$ & 0.01 & \\
\hline
\end{tabular}

Self-efficacy beliefs of an individual helps in improving the work efficiency by creating a meaningfulness in performing the job. Work is considered to be an element of identity by people because it is considered to be very important in people's life and a form of dignity (Blustein, 2011). Teachers' self-efficacy lifts the standard of content delivery as they are committed to performing their job with utmost sincerity. It also helps to build positive interactions with the students and colleagues. 'Self-efficacy, a belief in one's ability, helps in the process of adaptation to the world of work (Vieira, Maia, and Coimbra, 2007). The individual is motivated to perform meaningful work with a focus on the interest of self and the society, at large. The result, thus, proves that there is a significant effect of self-efficacy on the various dimensions of workplace spirituality.

The results of the relationship between self-efficacy and workplace spirituality and the moderating effect of knowledge sharing intention on this relationship are presented below.

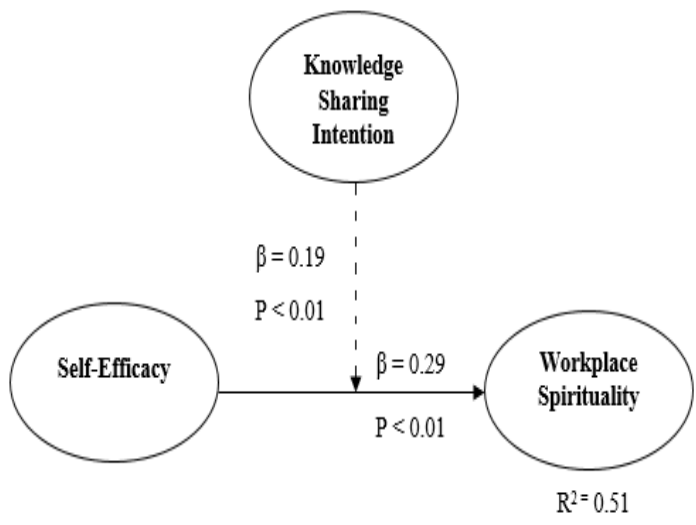

Figure 6 Model Showing the Result

The above model shows that there is a significant relationship between self-efficacy and workplace spirituality $(\beta=0.29, \mathrm{P}<0.01)$. The result shows that an increase in self-efficacy will lead to an increase in workplace spirituality. It also shows an $\mathrm{R}^{2}$ value of 0.51 . Knowledge sharing intention is seen to have a significant moderating effect on the relationship between self-efficacy and workplace spirituality $(\beta=0.19, \mathrm{P}<0.01)$. This indicates that the intention to share knowledge will strengthen the relationship between self-efficacy and workplace spirituality. Self-efficacy beliefs of an individual helps in building better connections with the work and the organization as a whole. Self-efficacious individuals involved in helping and supporting others and are also found to be interested in knowledge sharing. According to Sondergaard et al. (2007), the internal motivation of an individual helps in enabling or hindering the interest and willingness to share knowledge. The sharing of knowledge is directly linked to the inspiration of an individual and this is related to one's self-efficacy, due to which one decides to share knowledge with others in an organizational context. (Endres, et al., 2007). Especially in the case of teachers, knowledge sharing aming colleagues is very important and this can lead to the development of effective teaching methods and content. This will improve the standard of teaching and education as a whole. The belief in oneself, to an extent, influences the knowledge sharing intention of individuals. The analysis shows that knowledge sharing intention has a significant effect on the relationship between self-efficacy and workplace spirituality.

The goodness of fit for the proposed final model was also analyzed. The various goodness of fit statistics are shown in the below table. According to Kock (2013), the model has a good fit to the data.

Table 4 Model Evaluation Overall Fit Measurement

\begin{tabular}{|l|l|l|}
\hline Measure & Value & P-values \\
\hline APC $(<0.05)$ & 0.092 & $\mathrm{P}=0.004$ \\
\hline ARS $(<0.05)$ & 0.371 & $\mathrm{P}<0.001$ \\
\hline AARS & 0.349 & $\mathrm{P}<0.001$ \\
\hline AVIF & 1.889 & $\begin{array}{l}\text { Good if }<=5 \text {, ideally } \\
<=3.3\end{array}$ \\
\hline AFVIF & 2.113 & $\begin{array}{l}\text { Acceptable if }<=5, \\
\text { ideally }<=3.3\end{array}$ \\
\hline Tenenhaus GoF & 0.482 & $\begin{array}{l}\text { Small }>= \\
\text { medium }>=0.1, \\
\text { large }>=0.36\end{array}$ \\
\hline SPR & 0.783 & $\begin{array}{l}\text { Acceptable if }>=0.7, \\
\text { ideally }=1\end{array}$ \\
\hline RSCR & 0.916 & $\begin{array}{l}\text { Acceptable if }>=0.9, \\
\text { ideally }=1\end{array}$ \\
\hline SSR & 0.887 & $\begin{array}{l}\text { Acceptable if }>=0.7 \\
\text { Acceptable if }>=0.7\end{array}$ \\
\hline NLBCDR & 0.736 & \\
\hline
\end{tabular}

Source: - Data Analysis

The above values are indicative of a good fit of the model to the data. 


\section{IMPLICATIONS}

A sense of being capable empowers an individual to handle any situations and to engage in the various activities of the organization. It helps them remain positive in workplace, as self-efficacy is found to reduce workplace stress and burnout.

Positive behaviors and actions of the teachers is found to support the intellectual and personal development of the students. An employee's sense of completeness in profession is reflected through workplace spirituality. This sense of completeness is vital for the employees' as well as the organizations' sustainability. Knowledge sharing is another important factor that builds a positive environment. Knowledge sharing among teachers facilitates pedagogical improvisation, thereby, enabling them to create and deliver quality education. Although self-efficacy, workplace spirituality and knowledge sharing intention are personal level constructs, organizations can play a role in promoting these. As far as educational institutions are concerned, the schools (the principal and the management) have the responsibility of creating a work culture that enables teachers to increase their passion for their profession by helping them find meaning and completeness through a culture of having knowledge sharing among the members resulting in the upliftment of the quality of education.

\section{CONCLUSION}

All the three constructed studied here are, undoubtedly, beneficial for the individual as well as the organization. The perception of people towards their efficiency is the basic component underlying the aspects of behavior of people. The perception of people about their abilities, and these perceptions dictate how they will act in their work and workplace. An awareness of the capabilities of oneself will help in creating an attachment towards his/her own work and workplace. This feeling of attachment and involvement will help in increasing workplace spirituality. The experience of positivity in the organization improves the overall wellness of employees and reduces the undesirable consequences (Altaf and Awan, 2011). This will positively impact the performance both, at the individual level and organization level (Jurkiewicz and Giacalone, 2004). Promoting workplace spirituality is a win-win situation for both, the organization and the employees. Knowledge is the primary source of competitive advantage for the organizations. Stimulating a sense of knowledge sharing among the employees is absolutely essential to thrive in this era of competition. Knowledge sharing among organizational members stimulates innovation and grow and also enables faster decision making. The experience of workplace spirituality, which is an essential element that result in many positive outcomes, can be enhanced with self-efficacy beliefs and this relationship will become stronger in an environment of knowledge sharing. The study has, thus, proved that self-efficacy, workplace spirituality and knowledge sharing intention are closely related to each other.

\section{Limitations of the study}

The present study did not consider the influence of demographic variables in determining the concepts discussed. Future studies can attempt to understand the role of demographic factors like gender, age etc. in this scenario. Also future research might look into the role of organizational factors as well in enhancing the workplace spirituality, self-efficacy and knowledge sharing among teachers in a much larger sample.

\section{REFERENCES}

1. Afsar, B., \& Rehman, M. (2015). The Relationship between Workplace Spirituality and Innovative Work Behaviour: The Mediating Role of Perceived Person - Organization Fit. Journal of Management, Spirituality \&Religion, 12, 329- 353.

2. Ajala, E. M. (2013). The Impact of Workplace Spirituality and Employees 'wellbeing at the Industrial Sector: The Nigerian Experience. In The African Symposium: An online journal of the African Educational Research Network, (Vol. 13).

3. Altaf, A., \& Awan, M.A. (2011). Moderating effect of workplace spirituality on the relationship of job overload and job satisfaction. Journal of Business Ethics, 104(1), 93-99.

4. Amtmann, D. et al., (2012). University of Washington Self-Efficacy Scale: A New Self-Efficacy Scale for? People with Disabilities, 93.

5. Ashforth, B. E., \& Johnson, S. A. (2001). Which hat to wear? The relative salience of multiple identities in organizational contexts. In M. A. Hogg \& D. J. Terry (Eds.), Social identity processes in organizational contexts (pp. 31-48). Philadelphia, PA: Psychology Press.

6. Ashmos, D. \& Duchon, D. 2000. Spirituality at work. Journal of Management Inquiry, 9(2): 134-145.

7. Bakkenes I, Vermunt JD and Wubbels T (2010) Teacher learning in the context of educational innovation: Learning activities and learning outcomes of experienced teachers. Learning and Instruction, 20: 533548.

8. Bandura, A. (1977). Social learning theory. Englewood Cliffs, NJ Prentice Hall.

9. Bandura, A. (1982). Self-efficacy mechanism in human agency American Psychologist, 37, 122-147.

10. Bandura, A. (1994). Self-efficacy. In V. S. Ramachaudran (Ed.), Encyclopedia of human behavior (Vol. 4, pp. 71-81).

11. Bandura, A. (1997). Self-efficacy the exercise of control. Englewood Cliffs, NJ: Prentice-Hall.

12. Bandura, A., \& Locke, E. A. (2003). Negative self-efficacy and goal effects revisited. Journal of Applied Psychology, 88(1), 87-99.

13. Bandura, A. (2005). The evolution of social cognitive theory. In K.G. Smith \& M.A. Hitt (Eds.) Great Minds in Management. (p.1) Oxford: Oxford University Press.

14. Barnett, J.H. et al. (1999), "A business model of enlightenment", Journal of Business Ethics, Vol. 4 No.1, pp.57.

15. Baumeister, R.F., \& Leary, M.R. (1995). The need to belong: Desire for interpersonal attachments as a fundamental human motivation. Psychological Bulletin, 117(3), 497.

16. Brockner, J. (1988). Self-esteem at work. Lexington, MA: Lexington Books.

17. Blustein, D. L. (2011). A relation theory of working. Journal of Vocational Behavior, 79(1), 1-7. doi:10.1016/j.jvb.2010.10.004

18. Cerne, M., Nerstad, C., Dysvik, A., et al. (2014) What Goes around Comes around: Knowledge Hiding, Perceived Motivational Climate, and Creativity. Academy of Management Journal, 57, 172-192.

19. Chennamaneni, A., Teng, J.T., \& Raja, M.K. (2012). A unified model of knowledge sharing behaviours: Theoretical development and empirical test. Behaviour \& Information Technology, 31(11), 1097 1115.

20. Chin, W. W., Marcolin, B. L., \& Newsted, P. R. (2003). A Partial Least Squares Latent Variable Modeling Approach for Measuring Interaction Effects: Results from a Monte Carlo Simulation Study and an Electronic-Mail Emotion/Adoption Study. Information Systems Research, 14(2), 189-217.

21. Chow, W.S., \& Chan, L.S. (2008). Social network, social trust and shared goals in organizational knowledge sharing. Information \& Management, 45(7), 458-465. 
22. Clark, Nikki Bray, and Bates, Reid. (2003). Self-Efficacy Beliefs and Teacher Effectiveness: Implications for Professional Development. Volume XXVI, Number 1, Fall 2003.

23. Connelly, C.E. and E.K. Kelloway, (2003), "Predictors of employees" perceptions of knowledge sharing cultures,'Leadership \& Organization Development Journal, Vol. 24, No. 5: 294-301.

24. Davenport, T.H., \& Prusak, L. (1998). Working knowledge: How organizations manage what they know. Boston, Massachusetts: Harvard Business Press.

25. Dehler, G. E. and Welsh, M. A., (2003). The experience of work: Spirituality and the new workplace. In: R. A. Giacalone and C. L. Jurkiewicz, eds. Handbook of Workplace Spirituality and Organizational Performance. Armonk, NY: M.E. Sharpe, 108-122.

26. Dehler, G. E., \& Welsh, M. A. (1994). Spirituality and organizational transformation: Implications for the new management paradigm. Journal of Managerial Psychology, 9(6), 17-28.

27. Delbecq, L.A. (1999). Christian spirituality and contemporary business leadership. Journal of Organizational Change Management, 12(4):345-349.

28. Duchon, D. \& Plowman, D.A. (2005). Nurturing the spirit at work: impact on work unit performance. The Leadership Quarterly, 16(5):807-833

29. Dyer, J.H., P. Kale andH. Singh, (2004), "When to ally and when to acquire,"Harvard Business Review, Vol. 82, No.7/8: 108-117.

30. Endres, M. L., S. P. Endres, S. K. Chowdhury, and I. Alam, "Tacit knowledge sharing, self-efficacy theory, and application to the open source community," Journal of Knowledge Management, vol. 11, no.3, pp. 93-103, 2007.

31. Fairholm, G. W. (1996). Spiritual leadership: fulfilling whole-self needs at work. Leadrship and Organization Development Journal, 17(5), 11-17.

32. Fornell, C., \& Larcker, F. L. (1981). Evaluating Structural Equation Models with Unobservable Variables and Measurement Error. Journal of Marketing Research, 18, 39-50.

33. Freshman, B. (1999). An exploratory analysis of definitions and applications of spirituality in the workplace. Journal of Organizational Change Management, 12(4):318 Organizational performance. Armonk, NY: M. E. Sharpe.

35. Gibbons, P. 1999. Spirituality at work: Definitions, measures, assumptions and validation.

36. Goffee, R., \& Jones, G. (1996). What holds the modern company together? Harvard Business Review, 74, 133-148.

37. Groen, J. (2001), How leaders cultivate spirituality in the work place: What the research shows. Adult learning, 12.

38. Guillory, W.A. (2000). The Living Organization: Spirituality in the Workplace. Innovations International Inc., Salt Lake City, UT.

39. H. Takeuchi, The Knowledge-Creating Company, New York: Oxford University Press, 1995.

40. Hair, J., Babin, B., Money, A., \& Samouel, P. (2003). Essentials of Business Research Methods. New York: John Wiley \& Sons Inc

41. Hansen, M.T., Nohria, N., \& Tierney, T., (2002). What's Your Strategy For Managing Knowledge?. Harvard Business Review, pp. 106-16.

42. Harrington, W.J., Preziosi, R.C. and Gooden, D.J. (2001), "Perceptions of workplace spirituality among professionals and executives", Employee Responsibilities \& Rights Journal, Vol. 13, No. 3, pp. 155-63.

43. Hawley, J. (1993), Reawakening the Spirit in Work: The Power of Dharmic Management, Berrett-Koehler Publishers, San Francisco, CA.

44. Honingh M and Hooge E (2014) The effect of school-leader support and participation in decision making on teacher collaboration in Dutch primary and secondary schools. Educational Management Administration \& Leadership 42: 75-98.

45. Huber, G. P., 1991. Organizational Learning: The Contributing Processes and the Literatures. Organization Science, 2, 88-115.

46. Jurkiewicz, C.L., \& Giacalone, R.A. (2004). A values framework for measuring the impact of workplace spirituality on organizational performance. Journal of Business Ethics, 49(2), 129-142.

47. Kanter, R. M. (2006). Confidence: How winning and losing streaks begin and end. New York, NY: Crown Publishing.

48. Khari, C. \& Sinha, S. (2017). Impact of Workplace Spirituality on Knowledge Sharing Intention: A Conceptual Framework, Journal of Human Values, Sage, 23(1) 27-39.

49. Khorshid, Seddigheh (2015). The Effects of Workplace Spirituality and Teacher's Self-Efficacy Beliefs on His/Her Job Satisfaction. International Journal of Psychology. Vol. 9, No. 1, Winter \& Spring 2015, PP. 64-103
34. Giacalone, R. A. \& Jurkiewicz, C. L. (2003). Toward a science of workplace spirituality. Handbook of Workplace spirituality and

50. King, W. R. 2006. Knowledge Sharing, In: Encyclopedia of Knowledge Management, D. G. Schwartz, (Ed.), pp. 493-498, Idea Group Reference, ISBN 1-59140-573-4, Hershey, USA.

51. Kock, N. (2013). WarpPLS 4.0 User Manual, Script Warp Systems, Laredo $\quad$ Texas. $\quad$ Retrieved $\quad$ from 166 http://www.scriptwarp.com/warppls/UserManual.pdf

52. Kolodinsky, R. W., Giacalone, R. A., and Jurkiewicz, C. L., (2008) Workplace values and outcomes: Exploring personal, organizational, and interactive workplace spirituality. Journal of Business Ethics, 81, 465-480.

53. Kramer, R.M., (1999), "Social uncertainty and collective paranoia in knowledge communities: Thinking and acting in the shadow of doubt,'In Shared cognition in organizations: The management of knowledge, L.L. Thompson, J.M. Levine, and D.M. Messick (eds.) Lawrence Erlbaum, Mahwah, NJ, 163-194.

54. Kumar, Sunil. (2018). A Study of Perceived Workplace Spirituality of School Teachers. Psychological Thought, 2018, Vol. 11(2), 212-223.

55. Leigh, P. (1997). The new spirit at work. Training and Development, 51(3):26- 34.

56. Lin, H.F. (2007). Effects of extrinsic and intrinsic motivation on employee knowledge sharing intentions. Journal of Information Science, 33(2), 135-149.

57. Lin, H.F. (2007). Effects of extrinsic and intrinsic motivation on employee knowledge sharing intentions. Journal of Information Science, 33(2), 135-149.

58. Lindsey, K. L. 2006. Knowledge Sharing Barriers, In: Encyclopedia of Knowledge Management, D. G. Schwartz, (Ed.), pp. 499- 506, Idea Group Reference, ISBN 1-59140-573-4, Hershey, USA.

59. Liu, Caroline,H., and Robertson, P.J. (2011). Spirituality in the Workplace: Theory and Measurement. Journal of Management Inquiry, 20(1) 35-50.

60. Locke, E. A., \& Latham, G. P. (2002). Building a practically useful theory of goal setting and task motivation: A 35-year odyssey. American Psychologist, 57 (9), 705-717.

61. Marques, J., Dhiman, S., and King, R. (2007), Spirituality in the workplace: What it is, Why it Matters, How to Make it Works For You. Fawnskin: Personhood Press.

62. Maynard, H.B. (1992), "The Evolution of Human Consciousness", in Renesch, J. (Ed.), New Traditions in Business, Berrett-Koehler, San Francisco, CA, pp.39-52.

63. McWilliams, G.and M. Stepanek, (1998), "Knowledge management: Taming the info monster,'Business Week,Vol.3583: 170.

64. Miller, W.C. (1992), "How do we put our spiritual values to work?", in Renesch, J. (Ed.), New Traditions in Business: Spirit and Leadership in the 21st Century, Berrett-Koehler, San Francisco, CA pp. 69-80.

65. Milliman, J., Czaplewski, A.J., \& Ferguson, J. (2003). Workplace spirituality and employee work attitudes: An exploratory empirical assessment. Journal of Organizational Change Management, 4(16) 427-447.

66. Milliman, J., Ferguson, J. J., Trickett, D. \& Condemi, B. (1999) Spirit and community at Southwest Airlines: An investigation of a spiritual values-based model. Journal of Organizational Change Management. 12(3), 221-233.

67. Mirvis, P.H. (1997). 'Soul work' in organizations. Organization Science, 193-206.

68. Mitroff, I. I. \& E. A. Denton (1999). A Spiritual Audit of Corporate America: A Hard Look at Spirituality, Religion, and Values in the Workplace. Jossey-Bass, San Francisco.

69. Moore, T. W. (2008). Individual differences and workplace spirituality: The homogenization of the corporate culture. Journal of Management and Marketing Research, 1, 79.

70. Neal, J.A. (1998), "Research on individual spiritual transformation and work", paper presented at the Academy of Management Conference Symposium, San Diego, CA.

71. Neck, C.P. and Milliman, J.F. (1994), "Thought Self-leadership: Finding Spiritual Fulfilment in Organizational Life", Journal of Managerial Psychology, Vol.9 No.6, pp.9-16.

72. Nevid, J. S. (2009). Psychology: Concepts and applications (3rd ed.) Boston: Houghton Mifflin Company. Retrieved from http://books.google.com/books?id=LsVK0kSpzx8C.

73. Orr, J. (1990) Sharing Knowledge, Celebrating Identity: War Stories and Community Memory in a Service Culture. Collective Remembering Memory in Society. 
74. Paloutzian, R. F., Emmons, R. A. \& Keortge, S. G. (2003). Spiritua well-being, spiritual intelligence, and healthy workplace policy. In: R. A. Giacolone and C. L. Jurkiewicz (eds.) Handbook of workplace spirituality and organizational performance. M.E. Sharpe: New York, 123-137.

75. Pathak, D. (2012). Creativity \& Spirituality: Tools for Organizational Development. Creativity \& Spirituality: Tools for Organizational Development (December 31, 2012).

76. Pawar, B. S., 2008. Two approaches to workplace spirituality facilitation: A comparison and implications. Leadership \& Organization Development Journal, 29(6), 544-567.

77. Prilleltensky, I., \& Prilleltensky, O. (2007). Promoting well-being: Linking personal, organizational, and community change. Hoboken, NJ: Wiley.

78. Probst, G., S. Raub and K. Romhardt, (2000), Managing knowledge: Building blocks for success, John Wiley \& Sons, West Sussex, UK.

79. Ray, M.L. (1992), “ The Emerging New Paradigm in Business”, in Renesch, J. (Ed.), New Traditions in Business, Berrett-Koehler, San Francisco, CA, pp.25-38.

80. Reave, L. (2005). Spiritual values and practices related to leadership effectiveness. The Leadership Quarterly, 16(5), 655-687.

81. Reinholt, M., Pedersen, T. and Foss, N.J. (2011) Why a Central Network Position Isn't Enough: The Role of Motivation and Ability for Knowledge Sharing in Employee Networks. Academy of Management Journal, 54, 1277-1297.

82. Schwarzer, R., \& Jerusalem, M. (1995). Generalized Self-Efficacy scale. In J. Weinman, S. Wright, \& M. Johnston, Measures in health psychology: A user's portfolio. Causal and control beliefs (pp. 3537). Windsor, England: NFER-NELSON.

83. Shaari, R., (2014). Self-Efficacy as a Determined Factor for Knowledge Sharing Awareness. International Journal of Trade, Economics and Finance, Vol. 5, No. 1, February.

84. Skyrme, D.J., (2000), "Developing a knowledge strategy: From management to leadership,'InKnowledge management: Classic and contemporary works, D. Morey, M. Mayburry andB. Thuraisingham (eds.], The MIT Press,Cambridge, MA, 61-83.

85. Sondergaard, S., M. Kerr, and C. Clegg, "Sharing knowledge: Contextualizing socio technical thinking and practice," The Learning Organization, vol. 14, no. 5, pp. 423-435, 2007.

86. Srinivas, K.M. (2008). Spirituality-at-work in the land of dollar god. Journal of Human Values, 4(1), 45-64.

87. Stajkovic, A. D., \& Luthans, F. (2002). Self-efficacy and work-related performance: A metal-analysis. Psychological Bulletin, 124, 240-261.

88. Stajkovic, A. D. \& Sommer, S. M. (2000). "Self-efficacy and causa attributions: Direct and reciprocal links". Journal of Applied Social

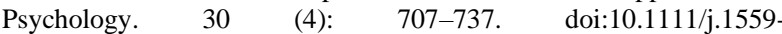
1816.2000.tb02820.x.

89. Steenkamp, P.L. \& Basson, J.S., 2013, 'A meaningful workplace: Framework, space and context', HTS Teologiese Studies/Theological Studies 69(1), Art. \#1258, 9 p http://dx.doi.org/10.4102/hts.v69i1.1258.

90. Teh, P.L., \& Yong, C.C. (2011). Knowledge sharing in IS personnel: Organizational behavior's perspective. Journal of Computer Information Systems, 51(4), 11.

91. Tischler, L., Biberman, J. \& McKeage, R. (2002). Linking emotional intelligence, spirituality and workplace performance: definitions, models and ideas for research. Journal of Managerial Psychology, 17(3):203-218

92. Tiwana, A., (2000), The knowledge management toolkit: Practical techniques for building a knowledge management system, PrenticeHall, New York.

93. Van Woerkom M (2004). The concept of critical reflection and its implications for human resource development. Advances in Developing Human Resources, 6: 178-193.

94. Vermuelen, Marjan, Runhaar, P.R., and Sanders K.K. (2014) Teachers' knowledge sharing: A study on the influence of work engagement, occupational self-efficacy and Human Resources Management on knowledge sharing. Educational Management Administration \& Leadership, 1-20.

95. Vieira, D., Maia, J., \& Coimbra, J. (2007). Do ensino superior para o trabalho: Análise factorial confirmatória da escala de auto-eficácia na transição para o trabalho (AETT). Avaliação Psicológica, 6, 3-12.

96. Wagner-March, F. \& Conely, J. (1999). The fourth wave: the spiritually-based firm. Journal of Organizational Change Management, 12(4):292-301.

97. Wang, S., \& Noe, R.A. (2010). Knowledge sharing: A review and directions for future research. Human Resource Management Review, 20(2), 115-131.
98. Wasko, M.M., \& Faraj, S. (2000). 'It is what one does': Why people participate and help others in electronic communities of practice. The Journal of Strategic Information Systems, 9(2), 155-173.

\section{AUTHOR PROFILE}

Rohini S. Nair, PGDM, is a doctoral student at Alagappa University having over nine years of experience in academics. She has presented papers in national and international conferences including IIM and has publications in reputed national and international journals.

Dr. V. Sivakumar, V. Sivakumar is an associate professor in the Alagappa Institute of Management having over 20 years of teaching experience including 10 years of research experience. He has published and presented papers in several international journals and national journals. 